\title{
One-for-One Companies: Helpful or Harmful?
}

\author{
Grace Taylor \\ Faculty Mentor: Jennifer Brass, School of Public and Environmental Affairs, Indiana University Bloomington
}

\begin{abstract}
One-for-one companies, such as TOMS and Warby Parker, have become a common occurrence in the marketplace. These companies promise to donate a good or service for every product purchased. To date, millions of products have been donated worldwide. This paper seeks to analyze the positive and negative impacts of the one-for-one model on both the one-for-one company and the people receiving product donations. A specific focus of the paper is to determine whether the one-for-one model is helpful or harmful to companies and beneficiaries. To gather information, I contacted sixteen one-for-one companies and asked for reports, gathered preliminary research completed by news outlets such as Forbes and the New York Times, and analyzed academic research. The study finds that the one-for-one model can be both helpful and harmful, depending on the conditions in which the giving is done. For example, if there is an immediate need for a good that cannot be produced in the beneficiary country, then a donation would be beneficial. However, if a donation such as shoes ultimately takes away jobs and reduces the market in the beneficiary country, then it causes more harm and long-term damage than it prevents. As this model becomes more common, it is important that consumers know the impact of their purchases on the beneficiaries and the companies know the benefits and repercussions of their actions.
\end{abstract}

KEYWORDS: one-for-one, aid, dependency, CSR, TOMS

\section{INTRODUCTION}

$\mathrm{Z}$ ep's Shoes had been planning on doing a shoe drop in Nagongera, a small town in Uganda, for months now. After talking to local community leaders and assessing the needs of the small town, Zep's took four employees to Nagongera to distribute shoes. In Nagongera, the employees gave shoes to over 200 kids aged 4-18. These shoes were equipped to handle the local weather, withstand miles of walking every day, and were allowed under the school uniform code. In Nagongera, the schools require black shoes; therefore, Zep's produced black shoes and believed their donation would ensure these students were able to continue attending school. However, Zep's has faced a lot of criticism after producing their shoes in a Chinese factory where workers are living in bad conditions. Critics have asked why the company is putting these workers at a disadvantage and why it cannot produce shoes in recipient communities such as Nagongera. Furthermore, there is a question of whether Zep's is helping these children or if it is putting local merchants out of business. While this story is fictional, the situation is a reality for some one-for-one companies.

The one-for-one business model is a relatively new business form intended to both turn a profit and also give back to a community. The essence of a sale made through one of these companies is that for every item purchased, an item is donated. One-for-one companies have given citizens of developed countries the opportunity to do something to help those in less developed countries, without having to make any dramatic changes to their budget or schedule. This has created an awareness of some of the problems that other countries are facing and given people a platform to help. These donations can be beneficial to recipients, as one-for-one companies sometimes provide products recipients may not otherwise be able to access.

While these one-for-one programs are intended to help developing countries, the programs might actually cause injury to developing economies because local companies cannot compete with the free goods that are coming into their country. It is also possible that the one-for-one programs are attempting to solve problems in the country that, in reality, are not important to the beneficiaries. However, onefor-one companies do not have to do much to prove they are helping other countries, as most people stop asking questions after seeing a positive image, such as a picture a child wearing a company's shoes on that company's Instagram page.
One-for-one companies participate in corporate social responsibility (CSR), which is a way companies give back to society. This can be done through donating a certain percentage of company profits each year or giving employees paid-time-off to volunteer, to name a few options among a myriad of ways to engage with the local community or with communities around the world. CSR specialist Howard Bowen describes CSR as "obligations...to pursue those policies, to make those decisions, or follow those actions which are desirable in terms of the objectives and values of our society" (Moon, 2014, p. 3). Essentially, CSR advocates believe it is the job of the business to be accountable to society and positively impact important causes, such as societal welfare (p.4). However, there has been controversy over whether companies are engaging in CSR to create a sustainable, positive change within a community or to gain more customers.

This new model of giving has sparked many companies to engage in similar activities, which has produced mixed responses. Some believe this helps generate more profit within a company while others believe this sort of activity takes money away from stockholders, who should bear responsibility for donating their money (Rogers, 2015). According to the PwC Global CEO Survey, "64\% of CEOs say that corporate social responsibility (CSR) is core to their business rather than being a stand-alone program" (Horoszowski, 2016).

The most well-known of these companies is TOMS, a shoe company devoted to giving a pair of shoes for every pair sold. The company has grown substantially since their first shoe donation in 2006. Having grown into an international phenomenon, TOMS now sells glasses, coffee, and bags globally, and in turn donates eye care, clean water and safe birthing kits, respectively. Since its founding in 2006, TOMS has "given more than 75 million pairs of new shoes to children in need" (TOMS, 2017a). TOMS was one of the first companies to globalize the trend in 2006, and it has been emulated by many other companies. Product (RED), which was launched in 2006 by Bono, branded certain products from many different popular brands, including Apple, Gap, and Converse, among an array of other companies. A portion of the sales from the Product (RED) brand went towards raising funds for the treatment of malaria, tuberculosis, and AIDS. This made it easy for consumers to make a difference through purchasing products they already would have bought (Ponte, Richey, \& Baab, 2010). These brands helped make donating "cool" 
and brought a good reputation to these companies because it made them appear sympathetic (Ponte, Rickey, \& Baab, 2010).

Since the emergence of the phenomenon, entrepreneurs have begun creating companies that donate products to locations close to their heart. The founder of Kutoa, Joey Grassia, came up with the idea of a brand that gives nutrient-rich bars to malnourished children when he went to South Asia. His company has gone on to donate over 200,000 meals to children worldwide since being founded in 2011 (Kutoa, 2017). This story is one of many describing one-for-one companies that have chosen to provide products and/or services to beneficiaries around the world.

This paper will examine the effects that companies such as TOMS are having in the communities to which they are donating. Additionally, it examines the effects this type of business has on the companies themselves. The paper seeks to answer the following questions: what is the impact one-for-one companies are having on beneficiaries? What are the lasting impacts these companies are having on beneficiaries? How much do companies profit off each sale versus how much they are giving to beneficiaries? These questions can be summarized by an overarching inquiry: what is the effectiveness of one-for-one companies on the recipients of donated goods, and what effects does the model have on the donating companies themselves? After researching sixteen different one-forone companies (Table 1), I find that there is a lack of information about the actual recipients of these donations. While the websites talk about the need for their products and the number of items the companies have given away, they do not mention the actual impact their company makes in these countries. If the companies do include this description on their webpage, it is normally a short paragraph containing a success story about the wondrous effects the company had on one recipient.

\section{THEORIES}

There are several existing theories regarding the effects of one-for-one companies. The following are explanations of four theories regarding the benefits and harms of one-for-one companies on beneficiaries and on the companies. Many of these theories provide different ideas regarding corporate social responsibility more generally, and how I see the one-for-one model as a form of CSR.

\section{Theory 1: The One-For-One Model Benefits Companies}

The first theory holds that one-for-one organizations are very effective and fill the gap that governments and International Nongovernmental Organizations (INGOs) are unable to fill due to lack of funds. Additionally, these companies excite consumers and influence them to care about impoverished people in other countries (Joyner, 2014). One-for-one companies will succeed because they are being held accountable by studies and social media.

According to this theory, as companies become larger and donate more, they are being held more accountable because "misuse of funds could cause irreparable harm to an organization's reputation" (Marquis and Park, 2014). If they receive bad press, people will immediately start buying from a competing organization, so the onefor-one organizations will treat their benefactors well. Companies will be influenced to be transparent and heavily track their donations to ensure they are actually helping the community to which they are giving.

This theory holds that consumers are more likely to buy from a company participating in charitable activities if the price is similar to the good they would have already purchased. In a report by The
Economist Intelligence stated " $74 \%$ of American executives believe that CSR can increase gains 'over time.' When asked their motives for doing CSR, 16\% of CSR companies stated that their company's goal was to raise revenue, while another $13 \%$ said it was to lower costs" (Blundin, 2012).

Furthermore, this theory believes the one-for-one model allows companies to connect with the market in a new way. It "allows the firm to clearly set out new actions and new behaviors that change how the firm interacts with the world and how value is created" (McPhee, 2014). Consumers see the firm through a new lens and will be curious to buy their product. This helps the company connect with consumers nationally and internationally, and creates the allusion, whether genuine or not, that the company is interested in improving the world.

\section{Theory 2: The One-For-One Model Holds Unintended Consequences for Companies}

Another theory holds that a company can fail if it unsuccessfully takes part in corporate social responsibility. Either the company tries to give too much and loses money, or it is involved in a scandal which causes irreparable damage to a company, causing it to shut down. According to Blundin (2012), participating in CSR can "lead to a certain degree of vulnerability for companies, which can shake the very foundations on which the business is built, which is operating to make a profit".

This theory also supports the idea that the CSR model is unsustainable because of the lack of preparation people are required to have before entering the field (Crespin, 2012). Crespin believes the profession is underdeveloped and lacks "recognition by society, an accepted body of knowledge...a recognized professional society, an ethics code [and] a professional credential”. Because the CSR profession lacks these aforementioned components, without some serious reform, the model will be unsustainable simply because of lack of knowledge and skills professionals possess concerning how to successfully implement CSR into a corporation.

Finally, this theory contends one-for-one companies are taking money that stockholders should be receiving and donating it, when in reality it should be the stockholders' decision whether or not they want to donate that money. Additionally, if stockholders decide to donate, the stockholders should be able to decide to what cause they want to give. Over time, the model will reduce the amount of stockholders invested in the company because they desire larger dividends.

\section{Theory 3: One-for-One Companies Benefit their Target Population}

While the first two theories discuss the impact the one-for-model has on companies, the following two theories examine the effects the model has on the one-for-one company's target population. This theory contends populations receiving aid from one-for-one companies are benefitting and receiving items they otherwise would not be able to access. While INGOs and governments cannot provide to all populations and often focus on providing for the poorest of the poor, one-for-one companies can focus their efforts on those populations that, while not desperate, will benefit immensely from donations (TOMS 2017e). More recent versions of this theory hold that, if a local industry is not being undermined, then it is acceptable for these populations to receive help from companies engaging in CSR (Wydick, Katz, and Janet, 2014, p. 15).

Furthermore, these companies are exposing children to the western world and are giving them access to people they otherwise may have never met (TOMS, 2017a). This provides them with the incentive to learn more and pursue an education. 


\section{Theory 4: One-for-One Companies Harm their Target Population}

Finally, the last theory focuses on the potential harm created by onefor-one companies. It holds that one-for-one organizations are not effective and actually harm more than they help these communities. Companies disadvantage the communities they are trying to help by creating a reliance on the organization to provide products for that community (Warby Parker, 2017). The product donations also put local merchants out of business, since the merchants cannot compete with free items. Many of the corporate organizations participating in this type of giving are doing so simply to increase profits and lower costs.

This theory also holds that organizations are participating in CSR to connect with millennials and increase sales. The one-for-one model has been accused of being a marketing tool not meant to truly benefit the recipients of aid. Schimmelpfenning believes "creating jobs that pay a fair wage and provide necessary benefits can have far more impact than aid" (Watkins, 2012). Most of their giving is for marketing purposes and not out of a sense of responsibility to help these communities. For example, after TOMS launched, Sketchers launched the brand BOBS that provided similar donations. Many viewed this as a disingenuous attempt to keep up with competition (Blundin, 2012).

Founder of Fashioning Change, Adriana Herrera, argues that “TOMS' business model depends on the continued existence of recipients who cannot afford its products; in other words, it requires the persistence of poverty" (Joyner, 2014). In an interview with Sebastian Fries, TOMS' chief donations executive, he stated the company is "not in the business of poverty alleviation" (Herrera, 2013). These companies are harming the populations they are trying to help by creating a dependency on one-for-one companies and INGOs to continually give them products.

Kelsey Timmerman travels the world and learns about the origin of clothes from the clothing industry. When traveling to Ethiopia, he spoke with a woman who stated "If you give a kid shoes, they wear out or they grow out of them, and then what do they have? If you give the kid's parents a job, the whole family will always have shoes" (Timmerman, 2011). He learned that TOMS was producing its shoes in China, which is not in line with their mission and does nothing to empower the communities to which it is donating.

\section{HYPOTHESIS}

After considering these four theories, I hypothesize one-for-one companies are detrimental to the communities to which they are donating goods, both economically and mentally, causing recipients to become dependent upon aid. This model is causing more harm than it does good.

\section{RESEARCH METHODS AND DATA}

This paper is primarily a literary review of existing research that has been conducted on one-for-one companies. It uses primary data collection as a supplement. Because the one-for-one model is relatively new, limited academic research has been done; however, news outlets such as Forbes, The New York Times, and The Economist, academics, and the companies themselves have completed preliminary research. All have shown patterns that outline the benefits and consequences of one-for-one donations in certain situations. Data limitations exist because of the few studies that have been completed in the communities that have received one-for-one donations, so this paper is relying on the best data available. There are additional data limitations due to the timeliness of articles written about these companies, many of them dating back to 2014 when the phenomenon was just taking off. Additionally, these companies publish very little material detailing their donations. Because of this, I also conducted original data collection for this project. I contacted 16 different one-for-one companies (Table 1) and asked them for annual donation reports or any other resources they were willing to share about their donations and impacts. I chose these specific companies to study because of their strong social media presence and impact of their donations. I heard back from TOMS, Roma, Figs, Bombas, This Bar Saves, One World Play Project, State, Out of Print Clothing, Warby Parker, and Better World Books. Notably, none of them were able to provide specific information about the number of donations they have contributed in specific communities.

\section{Data: What Have One-for-One Companies Done?}

This section presents data that corresponds with the four theories mentioned previously. The following four sections of data outline the benefits for companies and recipients and the harm the one-for-one model has on companies and beneficiaries.

\section{Benefits for Companies}

This section presents data about the benefits reaped by companies using the one-for-one model. Many companies have begun taking part in the one-for-one giving model, and many more have begun participating in some form of CSR. Consider Starbucks, which has begun sustainably sourcing some of its coffee and created its own fair-trade program. This trend is continually growing partially because "up to $93 \%$ of consumers state that they would be more likely to purchase an item that supports a cause" (Torres, 2012, p.12). Consumers have increased interest in purchasing from a socially responsible company, as $83 \%$ of people "would switch brands if a different brand supported a good cause” (Cone, 2012, p. 5).

Companies participating in CSR use this as a way to boost their sales, just as TOMS has built a following through their use of social media and online marketing. This has allowed them to "portray themselves as a company with a worthy purpose, rather than simply an active enabler of consumerism" (Torres, 2012, p. 11). TOMS shoes are clearly labeled with the brand, which Torres believes permits consumers to show friends and family their purchase and therefore devotion to the cause without having to say anything. This can lead to peer pressure from consumers' friends and family to make similar purchases (p. 12). As of 2011, TOMS did not have any form of paid advertising, instead relying on word of mouth and social media posts to obtain more consumers. In each shoe box, TOMS displays a flag and asks the consumer to post on social media with the flag (Spaulding, Fernandez, \& Sawayda, 2011, p. 3). Notably, TOMS has begun using targeted Facebook ads to reach consumers since this was published. There is a possibility of economies of scale, because if a company produces more of a specific good to reduce its marginal cost, they still could increase profit by giving away some of those goods.

Many leaders in the business world have found benefits in participating in CSR. The Economist Intelligence Unit conducted a study of 200 CSR executives and found that $74 \%$ believed participating in social responsibility would increase their profits (2008). Notably, the data comes from a select group of executives, and those who do not believe CSR benefits their company are likely not present in this sample. As of 2014, TOMS founder Blake Mycoskie's personal worth is over $\$ 300$ million (O'Connor, Forbes, 2014). Furthermore, the buy-one-give-one model also helps attract top talent to a company. TOMS has been able to hire people from the top shoe companies in the United States, 
APPLIED SCIENCES

Table 1.

16 Popular One-for-One Companies

\begin{tabular}{|c|c|c|c|c|c|}
\hline Company & Sells & Donates & Where & Positive Effects & Negative Effects \\
\hline TOMS & $\begin{array}{l}\text { shoes, } \\
\text { coffee, bags, } \\
\text { sunglasses }\end{array}$ & $\begin{array}{l}\text { shoes, glasses, water } \\
\text { systems, safe birth kits, } \\
\text { bullying prevention }\end{array}$ & $\begin{array}{l}70+\text { countries } \\
\text { worldwide }\end{array}$ & $\begin{array}{l}\text { improved health, access to } \\
\text { education, safe birth }\end{array}$ & $\begin{array}{l}\text { Are shoes a } \\
\text { sustainable donation } \\
\text { that help long term? }\end{array}$ \\
\hline $\begin{array}{l}\text { One World } \\
\text { Play Project }\end{array}$ & $\begin{array}{l}\text { soccer balls, } \\
\text { durable dog } \\
\text { toys }\end{array}$ & durable soccer balls & $\begin{array}{l}\text { Central and } \\
\text { South America, } \\
\text { Africa, Asia }\end{array}$ & $\begin{array}{l}\text { have donated over } 1 \text { million } \\
\text { balls, enable many to play who } \\
\text { wouldn't have chance }\end{array}$ & $\begin{array}{l}\text { waste of unused } \\
\text { soccer balls }\end{array}$ \\
\hline Bixbee & $\begin{array}{l}\text { backpacks, } \\
\text { lunch boxes, } \\
\text { duffel bags }\end{array}$ & $\begin{array}{l}\text { schoolbags full of } \\
\text { supplies to a kid in } \\
\text { need }\end{array}$ & $\begin{array}{l}\text { Philippines, } \\
\text { Rwanda, Haiti, } \\
\text { India, Thailand, } \\
\text { United States }\end{array}$ & $\begin{array}{l}\text { donate yellow backpacks to } \\
\text { encourage motorists to slow } \\
\text { down as kids walk to class, } \\
\text { source and produce backpacks } \\
\text { and supplies locally }\end{array}$ & unknown \\
\hline Bombas & socks & socks to the homeless & United States & $\begin{array}{l}\text { socks are anti-microbial with } \\
\text { reinforced seams and don’t } \\
\text { need washed a lot, donated } \\
4,426,080\end{array}$ & unknown \\
\hline Roma & boots & $\begin{array}{l}\text { boots to children } \\
\text { in need, } 10 \% \text { of } \\
\text { funds goes toward } \\
\text { educational initiatives }\end{array}$ & $\begin{array}{l}\text { Asia, Europe, } \\
\text { Australia, } \\
\text { Americas, Africa }\end{array}$ & $\begin{array}{l}\text { support education, boots to } \\
\text { kids in snowy areas who may } \\
\text { not have access to them }\end{array}$ & $\begin{array}{l}\text { Are boot donations } \\
\text { impacting local boot } \\
\text { vendors? }\end{array}$ \\
\hline Smile Squared & $\begin{array}{l}\text { toothbrushes, } \\
\text { travel journals }\end{array}$ & toothbrushes & $\begin{array}{l}\text { United States } \\
\text { and } 20 \text { countries } \\
\text { worldwide }\end{array}$ & $\begin{array}{l}\text { help prevent cavities which } \\
\text { prevents many dental problems }\end{array}$ & $\begin{array}{l}\text { Do kids get one } \\
\text { toothbrush or } \\
\text { are the donations } \\
\text { continuous? }\end{array}$ \\
\hline SoapBox & $\begin{array}{l}\text { body, bar, and } \\
\text { hand soap }\end{array}$ & bars of soap & 60 countries & $\begin{array}{l}\text { possibly saved } 3,300 \text { lives } \\
\text { with handwashing, have given } \\
1,700,000 \text { bars, team with local } \\
\text { partners }\end{array}$ & $\begin{array}{l}\text { no way to measure } \\
\text { true impact, What } \\
\text { type of soap is being } \\
\text { donated? }\end{array}$ \\
\hline Figs & $\begin{array}{l}\text { medical } \\
\text { scrubs, casual } \\
\text { clothing }\end{array}$ & $\begin{array}{l}\text { scrubs to healthcare } \\
\text { providers }\end{array}$ & $\begin{array}{l}34 \text { countries, } \\
\text { mostly Central } \\
\text { America and } \\
\text { Africa }\end{array}$ & $\begin{array}{l}\text { "Clean scrubs reduce hospital- } \\
\text { acquired infection rates by } \\
66 \% \text { ", donated over } 75,000 \\
\text { sets, best in the world for } 2015\end{array}$ & unknown \\
\hline $\begin{array}{l}\text { Better World } \\
\text { Books }\end{array}$ & $\begin{array}{l}\text { new and used } \\
\text { books }\end{array}$ & $\begin{array}{l}\text { books and grants for } \\
\text { literacy programs }\end{array}$ & worldwide & $\begin{array}{l}\text { diverted more than } 250 \text { books } \\
\text { from landfills, donated over } \\
21 \text { million books to partner } \\
\text { programs, } \$ 616,744 \text { grants } \\
\text { given to } 64 \text { programs }\end{array}$ & $\begin{array}{l}\text { What happens to the } \\
\text { books once they are } \\
\text { donated and used? }\end{array}$ \\
\hline State & $\begin{array}{l}\text { backpacks, tote } \\
\text { bags }\end{array}$ & $\begin{array}{l}\text { hand-delivers a } \\
\text { backpack with supplies }\end{array}$ & $\begin{array}{l}\text { underfunded } \\
\text { neighborhoods in } \\
\text { New York City }\end{array}$ & $\begin{array}{l}\text { provides kids in underfunded } \\
\text { neighborhoods with backpacks } \\
\text { and supplies }\end{array}$ & $\begin{array}{l}\text { Issues with jealousy } \\
\text { of kids without the } \\
\text { backpacks? }\end{array}$ \\
\hline Project 7 & $\begin{array}{l}\text { chewing gum \& } \\
\text { gummies }\end{array}$ & $\begin{array}{l}\text { plant trees, emergency } \\
\text { shelter provide meals, } \\
\text { clean drinking water, } \\
\text { malaria treatments, } \\
\text { daily school education, } \\
\text { anti-bullying programs }\end{array}$ & worldwide & $\begin{array}{l}\text { spread the wealth among many } \\
\text { different missions, planted } \\
4.3 \text { million trees, } 4 \text { million } \\
\text { meals to hungry, } 116 \text { thousand } \\
\text { treatments for malaria, } 1.4 \\
\text { million months of clean } \\
\text { drinking water }\end{array}$ & $\begin{array}{l}\text { spreading themselves } \\
\text { across a huge array- } \\
\text { hard to keep track of } \\
\text { all of the beneficiaries } \\
\text { to ensure their } \\
\text { initiatives are } \\
\text { successful }\end{array}$ \\
\hline $\begin{array}{l}\text { Out of Print } \\
\text { Clothing }\end{array}$ & $\begin{array}{l}\text { clothing, mugs, } \\
\text { tote bags }\end{array}$ & $\begin{array}{l}\text { books, fund literacy } \\
\text { programs and book } \\
\text { donations }\end{array}$ & unknown & $\begin{array}{l}\text { supporting literacy and the } \\
\text { authors, publishers and artists }\end{array}$ & $\begin{array}{l}\text { lack of information } \\
\text { on website of } \\
\text { donations }\end{array}$ \\
\hline
\end{tabular}


Table 1 (continued).

16 Popular One-for-one Companies

\begin{tabular}{|c|c|c|c|c|c|}
\hline Company & Sells & Donates & Where & Positive Effects & Negative Effects \\
\hline Kutoa & health bars & $\begin{array}{l}\text { micronutrient packs, } \\
\text { PlumpyNut packs, } \\
\text { KUTOA Bars }\end{array}$ & South Asia & $\begin{array}{l}\text { malnutrition is the number } 1 \\
\text { cause of childhood morality, } \\
\text { child dies every } 6 \text { seconds, } \\
\text { donated 200,000 meals since } \\
2011\end{array}$ & $\begin{array}{l}\text { Is their giving } \\
\text { sustainable? Is } \\
\text { it hurting local } \\
\text { markets? How do } \\
\text { they consistently help } \\
\text { the community? }\end{array}$ \\
\hline $\begin{array}{l}\text { WeWood } \\
\text { (an Italian } \\
\text { company) }\end{array}$ & $\begin{array}{l}\text { wooden watches, } \\
\text { glasses }\end{array}$ & trees & $\begin{array}{l}\text { Peru, countries } \\
\text { in Africa, China } \\
\text { Mangroves, } \\
\text { Philippines, } \\
\text { Malaysia }\end{array}$ & $\begin{array}{l}\text { goal to plant } 1 \text { million trees by } \\
2020 \text {, have planted } 442,246 \\
\text { trees planted so far }\end{array}$ & $\begin{array}{l}\text { How to ensure their } \\
\text { trees are surviving? }\end{array}$ \\
\hline $\begin{array}{l}\text { This Bar Saves } \\
\text { Lives }\end{array}$ & health bars & $\begin{array}{l}\text { have donated } \\
33,063,063 \text { meal } \\
\text { packets }\end{array}$ & $\begin{array}{l}\text { Haiti, DRC, } \\
\text { Philippines, } \\
\text { South Sudan, } \\
\text { Guatemala, } \\
\text { Mexico }\end{array}$ & $\begin{array}{l}\text { malnutrition kills } 2.6 \text { million } \\
\text { kids every year ( } 1 \text { child every } \\
12 \text { seconds), use ingredients } \\
\text { that don't need refrigerated }\end{array}$ & $\begin{array}{l}\text { How sustainable are } \\
\text { these gifts? What } \\
\text { happens after a child } \\
\text { is past starvation? }\end{array}$ \\
\hline Warby Parker & $\begin{array}{l}\text { eyeglasses, } \\
\text { sunglasses }\end{array}$ & $\begin{array}{l}\text { glasses for free or at } \\
\text { a reduced rate, train } \\
\text { locals to perform eye } \\
\text { exams }\end{array}$ & $\begin{array}{l}\text { United States and } \\
\text { worldwide }\end{array}$ & $\begin{array}{l}1 \text { billion worldwide lack access } \\
\text { to glasses, glasses allow them to } \\
\text { work, which increases produc- } \\
\text { tivity and monthly wage }\end{array}$ & $\begin{array}{l}\text { How sustainable are } \\
\text { these gifts? What } \\
\text { happens after a child } \\
\text { is past starvation? }\end{array}$ \\
\hline Twice as Warm & $\begin{array}{l}\text { hats, gloves, } \\
\text { scarves }\end{array}$ & $\begin{array}{l}\text { donates warm clothing } \\
\text { to homeless shelters }\end{array}$ & United States & provides clean, warm clothes & $\begin{array}{l}\text { How to avoid } \\
\text { dependency? How } \\
\text { to help them past } \\
\text { receiving clothes? }\end{array}$ \\
\hline
\end{tabular}

including Nike and ASICS, because people want to work for a cause bigger than themselves (Flandez, 2011).

\section{Unintended Consequences for Companies}

While there are many benefits to the one-for-one model, there are also unintended consequences. A company's participation in onefor-one giving can help sales, but it also makes the company more vulnerable toward criticism, should it do something wrong. Because this form of giving is relatively new and product donations widely vary, there is not a perfect model for donation. According to Vogel, "the long-term performance of socially responsible investment funds has been no better, or worse, than those funds that use other criteria to predict shareholder value" because at the end of the day, consumers make purchases based on the price and quality and not the mission of the company (Vogel, 2008).

Shortly after the founding of TOMS, Sketchers followed suit and began BOBS, which had the same promise of donating shoes one-forone. However, many viewed Sketchers new line as a disingenuous attempt to turn a profit (Blundin, 2012). Blundin believes companies are racing to participate in CSR, without thinking about the longterm implications and consequences of this form of donation (p. 5).

\section{Benefits to Recipients}

In considering the benefits and consequences to companies, it is also important to consider the effects donations are having on recipients. Millions of products and services have been provided around the world by one-for-one companies. Figure 1 provides data on the three biggest companies. At TOMS, since being founded, it has donated over "75 million pairs of new shoes to children in need" (TOMS, 2017a). TOMS believes that its donations of shoes support "improved health, access to education [and] confidence building" (TOMS, 2017a). In addition to shoes, TOMS has provided eye treatment and exams for over 500,000 people (TOMS, 2017c), 450,000 weeks of safe water (TOMS, 2017c), safe birth kits to over 175,000 mothers, and bullying-prevention backpacks to students (TOMS, 2017a). Shoes prevent disease and also help promote education, as shoes are often a requirement to attend school, so TOMS helps fill in the gap in these respects (Spaulding, et. al., 2011, p. 3). Additionally, TOMS modifies their shoes to the needs of the beneficiary; for example, TOMS gives thicker rubber-soled shoes to those in areas with monsoons (p. 6).

Other clothing companies-such as Bombas, which has donated over 4 million pairs of socks to the homeless in the United States (Bombas, 2017), and Warby Parker, which has given over 3 million pairs of glasses (Warby Parker, 2017)-have followed a similar buy-one-give-one model. Companies often donate backpacks as well. Bixbee donates yellow backpacks full of supplies to children worldwide. The company uses yellow because it is an international symbol to yield, and many of the children receiving the backpacks are walking for miles on busy roads to get to class (Bixbee, 2017). TOMS also donates backpacks full of resources to prevent bullying. State sells high fashion bags and then hand delivers backpacks full of supplies to children in underfunded neighborhoods in New York City.

In addition, food companies and companies that sell an item and donate a different product have also become popular. The Italian company WeWood sells watches and glasses, and plants a tree for every product sold, having donating 442,264 trees since its founding in total (WeWood, 2017). WeWood allows consumers to click on 
Largest Donors: One-for-One Donations

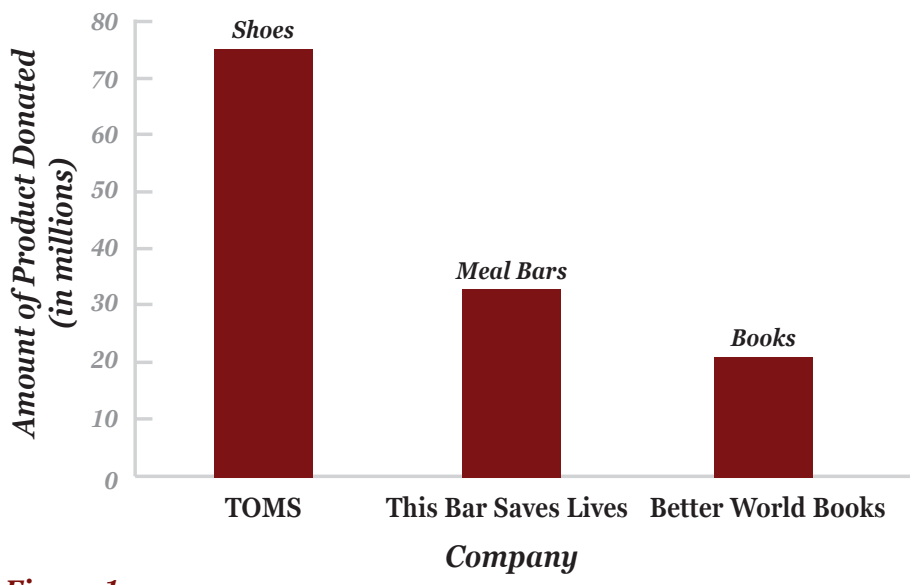

Figure 1.

Product donation number from the three largest donors.

different parts of the world and see exactly where the company has donated and how many trees were planted at each location. Project 7 has planted trees worldwide, totaling over 4.3 million trees (Project 7, 2017).

Companies are also providing services in exchange for products purchased. In addition to providing glasses to beneficiaries at a discounted rate, they also teach locals how to conduct basic eye exams (Warby Parker, 2017). Other companies, such as Better World Books and Roma, are giving money toward educational initiatives. Better World Books has given away over $\$ 616,000$ in grants since being founded in 2002, which have funded 64 programs (Better World Books, 2017a).

\section{Unintended Consequences of Giving to Recipients}

With benefits to the recipients also comes the question of the consequences to recipients. A study conducted by academics at University of San Francisco researched 979 households in El Salvador, giving half of the households children's shoes and the other half coupons to buy shoes locally. Through this, researchers reached 5,607 individuals in 18 different rural communities. Half of the coupons were for less expensive, $\$ 10$ shoes, while the other ones were valid for $\$ 20$ shoes. The shoes given to the locals were very similar to those given by TOMS. In these communities, almost all children had access to at least one pair of shoes. Researchers found that "donated shoes exhibit negative impacts on local shoe markets" but the impacts were not large enough to be of statistical evidence (Wydick, Katz, and Janet, 2014, p. 15). This did not evaluate the long-term impacts of giving.

In reference to the long-term impacts of one-for-one giving, Reed states, "Two potentially negative outcomes arise: the impact is either unsustainable, lasting only as long as the product does; or worse, the model promotes aid-dependency" (Reed, 2017). This issue of aid-dependency, or relying on donations to sustain a community, has been presented as a concern in recent studies. In fact, $66 \%$ of the kids who did not receive shoes in the El Salvador study believed other people should provide for their family (The Economist, 2016). However, after being the subject of the El Salvador study, TOMS has been responding to criticisms regarding the production location of the shoes and has developed glasses to help work toward fixing the global issue of poor vision through their one-for-one glasses program (Reed, 2017). Evident on the TOMS website, employees are working toward solving issues with the production locations of their shoes and making changes toward their donation model in response to criticisms.

While the products may not necessarily be harming the beneficiaries, they are not helping them as much as other programs could. Research finds in-kind donations to have had negative impacts on the local economies (Wydick, Katz, \& Janet, 2014, p. 2-3).

Another piece of evidence that these programs are considered negative is East African countries just banned the import of used clothing, signifying they have no desire for free goods entering their market and injuring their domestic textile industry. In Africa, "secondhand merchandise is the primary source of clothing- much as it is for cars, planes, hospital equipment, computers and sometimes even drugs that have passed their expiration date" (Freytas-Tamura, 2017). East African countries want to facilitate the growth of local business that could eventually compete globally. Over $70 \%$ of used clothing goes to Africa. This ban could lead to the loss of about 40,000 American jobs (Freytas-Tamura 2017).

\section{ANALYSIS}

The data suggests that companies benefit from the one-for-one model under certain conditions. Additionally, very limited data were found regarding the costs of giving for a company, making it difficult to assess the negative impacts of the one-for-model on companies. Furthermore, while there are benefits under certain conditions to recipients, many of these one-for-one companies could be helping more using different donation tactics. Notably, there are very limited data, so these results are primary.

\section{Is the One-for-One Model Truly Beneficial to Companies?}

\section{Benefits}

There are many benefits for companies to participate in CSR. Evidence states that over $83 \%$ of U.S. consumers would begin buying from a socially conscious company, suggesting the theory that one-for-one models are beneficial to companies proves true (Cone, 2012, p. 5). Companies benefit greatly from CSR under the right circumstances. They can use one-for-one giving as a way to market, and oftentimes they use it as their only form of advertising. As proven by TOMS, the use of social media excites consumers and makes them want to buy similar products due to peer pressure and the desire to wear something that shows they are making a difference. Corporate companies benefit from this model if they are engaging with the market in a way that excites consumers and influences them to buy from their company.

\section{Costs}

While there are benefits, there are also costs to companies participating in CSR. With Starbucks, the company saw a great loss in stock after announcing plans to engage in fair trade. However, TOMS utilizes the one-for-one giving as an essential part of their business model and has become a multimillion dollar company.

There are no data that show how one-for-one companies are truly making a large difference in the places they are giving, nor is there a uniform process the companies must complete to maintain accountability to the public. Additionally, there are no data suggesting that, should a company not follow through on its mission, the market would choose to buy from another one-for-one company that is more loyal to its mission. While researching online, there was no particular website that could be used to research which companies were following through with their promised donations. Additionally, when I asked the companies for any donation information, none were 
able to provide substantial data.

Critics of the model believe "In reality, companies engaging in buy-to-give efforts are in the business of selling ego boosts disguised as social change, popularized by our ability to craft the appearance of an altruistic persona by placing Toms shoes on our feet, artisanal jewelry made from disenfranchised women around our necks, and carefully curated images on our social media accounts" (Jazner \& Weinstein, 2015). There are economic costs, and there are also humanitarian costs. Depending on the model of giving, the business form may just be beneficial for the consumers and companies, and not for the beneficiaries. In this case, it depends on the intention of the company for engaging in the one-for-one giving. Companies need to ask themselves what impact they want to leave on their beneficiaries.

However, there is not enough information to be able to firmly support or deny that this model is detrimental to companies. There has been very little research done recently that looks at consumers' purchases based on the mission of a company.

\section{Are the Beneficiaries' Lives Truly Being Bettered Because of These Donations?}

There has very clearly been a large amount of goods sent overseas as donations to various communities worldwide (Figures One \& Two). There is no easy way to determine whether a beneficiary's life has been bettered because of the donation of a one-for-one company, simply because there is such a wide array of goods that they may be receiving, from bars of soap, to bars of food, to shoes.

Multiple researchers have concluded that the Warby Parker model has been widely effective. Instead of simply giving away glasses, the company partners with local companies and community leaders to teach people how to administer eye exams, rendering their services useful and effective in the long run. One of the founders of Warby Parker, Neil Blumenthal, contends that the model makes "a needy beneficiary into a responsible consumer. It treats them with greater dignity" (Wharton, 2015). Warby Parker has paired with VisionSpring, which trains "low-income entrepreneurs to start their own businesses selling glasses to their communities at an affordable price" (Schwabel, 2016). This partnership has enabled VisionSpring to be able to focus on the needs of each particular community.

Each of the top 16 One-for-One companies had substantial reasoning as to why they were giving and were very clearly hoping to make a positive impact with their donations (Table 1). However, there has not yet been enough research done on the different forms of donations to determine the true impact this form of giving has had on the beneficiaries and their local economies. While trees being planted fill an obvious gap in the lack of greenery in certain places, there is still a question of whether the companies are planting trees that are native to that area and that are wanted by the natives.

The El Salvador study concluded that after receiving shoes, many more children wore them at least 4 days a week, in comparison with the amount that they had been wearing them before (Wydick, et al., 2014, p. 6). Researchers also found there was not a significant impact on the local economy. However, just because a one-for-one company is not doing explicit harm does not mean the company is necessarily making a positive, sustainable impact on a community, either.

Ultimately, the beneficiaries are positively impacted under certain conditions, and beneficiaries around the world cannot be grouped together as one giant group in need of the same goods and services. There are so many different conditions under which a donation will truly make a difference. However, with a company like Figs, which donated medical scrubs, it is fulfilling a need that had not yet been filled in the beneficiary communities. Clean medical scrubs from Figs help "reduce hospital-acquired infection rates by 66\%" (Figs, 2017a). In this case, Figs is filling a need and is helping to solve a problem that otherwise would have remained unaddressed.

\section{Do the Consequences of One-for-One Giving Harm Beneficiaries More Than They Help?}

There have been considerable growing pains as companies have given overseas. Originally, TOMS was producing all of their shoes in China and giving them to other impoverished communities (Timmerman, 2011). After this news became public, TOMS began to change its model so that more of the shoes were being manufactured in the beneficiary country. Additionally, it recently added the different types of shoes given to children to its website, which now includes a winter boot, waterproof slip-on, sports shoe, and their classic canvas shoe (TOMS, 2017a).

The most recent TOMS Giving Report of 2013 addressed some consumer concerns, making clear the company only donates to places where it will not hurt local business. It also talks about the changes the company is making to the shoes, per request of the recipients. Furthermore, TOMS makes it clear that when it can donate, it donates repeatedly to a certain place to ensure children continually have shoes as they grow up (TOMS Giving Report, 2013). However, for the amount of giving done each year by TOMS, the Giving Report is inadequate in reporting where the shoes go, the actual impact, and the reactions of the beneficiaries. On the TOMS website, the company writes about the supposed benefits of its donations. For example, TOMS believe shoes provide kids with "improved health, access to education, [and] confidence building" yet fail to provide any statistical evidence of these impact (TOMS, 2017a). An issue that has arisen with donations to other countries is the impact of potential competition with the goods being donated versus the goods being produced in a host country. Many governments have raised tariffs to protect infant industries so that they can "develop infrastructure and economies of scale" (Pettinger, 2017). There has yet to be action taken against goods being donated by one-for-one companies in beneficiary countries, but if they begin to hurt local economies, then

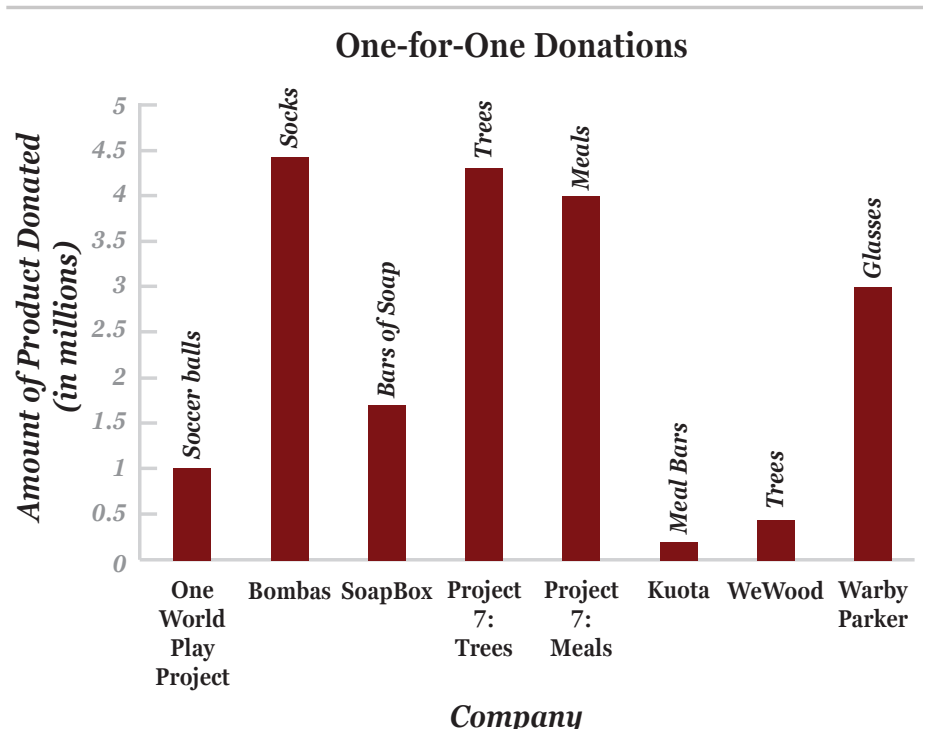

Figure 2.

Product donation numbers from other one-for-one companies. 
there is a possibility of raised quotas and higher tariffs.

Given the current research, there has been no significant change to local markets. However, the El Salvador study has been the only study that has done significant research in the area, and it was focused solely on shoes. This study did not find any immediate significant impacts on the local economy, but there has been little to no research done on the long-term impacts.

There are many other companies involved in giving shoes. Torres refers to the company SoleRebels, an Ethiopian business that employs locals and teaches them life skills, while paying three times the normal wage. She believes this is a model that TOMS should consider using, to cultivate local business and consumerism, as "this type of business model helps to build the community by providing a way for locals to earn their way to a better life, rather than being given a handout" (Torres, 2012, p. 10). While many of the leading models may need some modifications to achieve maximum impact, there are other companies using a more effective approach to donations.

Furthermore, criticisms have arisen about the products being given to recipients, as recipients have little to no say in the products that they are given (Janzer \& Weinstein, 2015). Janzer and Weinstein state, "What's missing from the intentionality behind these initiatives is the understanding that people are intelligent enough to solve their own problems, and only lack the resources and agency to act on solutions" (2015). One-for-one company Warby Parker, donor of over 3 million pairs of glasses worldwide, states "It's a sticky facet of life that kind-hearted gestures can have unintended consequences. Donating is often a temporary solution, not a lasting one. It can contribute a culture of dependency. It is rarely sustainable" (Warby Parker, 2017).

There have been criticisms of many different CSR companies. In regard to the Product (RED) campaign, many people criticized it because they believed it was "glossing over serious concerns about the international political economy and the consequences of increased consumption with celebrities and a shallow form of "activism" (Youde, 2009). However, Youde discovered that, while the critics make a good point, the reality of the situation is that the international recognition of issues such as AIDS was much preferable to people remaining ignorant about the disease (2009).

There are many issues that still need addressing with one-for-one companies, thus supporting the theory that one-for-one companies are doing harm. The question still remains of whether or not the harm outweighs the good. As Youde mentions, it could be better that consumers are conscious of these issues and are attempting to make a change, instead of doing nothing at all.

\section{DISCUSSION AND CONCLUSION}

Given the wide array of information from one-for-one companies, there is no simple answer as to whether one-for-one companies are helpful or harmful. Given the data, there are conditions under which companies can be helpful, so it is important to know what those conditions are if one-for-one companies do not want to hurt people. In most situations, I found a mixture of benefits and costs to both the companies and the beneficiaries. As more companies decide to participate in some form of one-for-one giving, there needs to be a central form to hold companies and their community partners accountable and ensure the beneficiaries are being assisted in a sustainable, dignifying manner.

Nonprofit organizations in the United States must provide detailed reports of their financials and donations, and corporations have to provide detailed tax information. However, there is a gap for these one-for-one as they fail to disclose imperative information that consumers should have access to before they make their purchase.
Just as donors can research the financials of nonprofits, consumers should be able to have access to information on giving, instead of just being exposed to the glorified social media accounts of the brands giving their products away.

Limitations as I completed this research included a lack of information on the one-for-one websites. Many of these newer companies have very little data about the amount they have given. It is difficult to assess negative implications of their gifts without having access to data and feedback from beneficiaries. There is also a limitation in the scope of the organizations. While Keuta has donated 200,000 meals since 2011 (Kuota, 2017), Project 7 has donated 4 million meals (Project 7, 2017). There is no central way to compare organizations because of the grand differences in terms of the company's size and scope.

There are many questions about the long-term impact of onefor-one companies that have yet to be answered by current research, including:

- What happens in beneficiary countries if parents lose jobs because the current market cannot compete with free donations? What happens if the short-term donation of shoes intended to help a child get to school results in their parents being unable to afford school?

- What happens with the waste of the products after they are no longer usable? Do these donations create a dependency on aid?

Critics have made the argument that a child cannot eat shoes. However, if these children cannot attend school without shoes, are they really better off without the help of a one-for-one company? Jazner and Weinstein pose the question, "When our only connection to social change is a status item, we have to ask ourselves: who is this effort really about?” (2015). Ultimately, there is no correct answer; instead, the help or harm a one-for-one company provides is dependent on their intentionality, research, and the conditions in which the company gives.

\section{AUTHOR INFORMATION}

All correspondence should be sent to the first author:

gracealden1@yahoo.com

\section{REFERENCES}

Better World Books. (2017a). "Great prices on new and used books.” Retrieved November 06, 2017, from https://www. betterworldbooks.com/info.aspx

Better World Books. (2017b). "Partners." Retrieved November 06, 2017 from https://www.betterworldbooks.com/info. aspx?f=Partners

Bixbee. (2017). Retrieved November 06, 2017, from http://www. bixbee.com/mission/

Blundin, C. (2012). Corporate social responsibility: Fallacies and flaws. Johnson \& Wales University, Providence, RI.

Bombas. (2017). “Giving back.” Retrieved November 06, 2017, from https://bombas.com/pages/giving-back

Chandler, D. B., \& Werther, W. B. (2014). Strategic corporate social responsibility: Stakeholders, globalization, and sustainable value creation (3rd ed.). Thousand Oaks, CA: Sage Publications, Inc. 
Cone, C. (2012). Executive summary: Goodpurpose 2012 [PDF]. Edelman.

Crespin, R. (2012, April 12). Corporate Sustainability Is Itself Unsustainable. Retrieved December 10, 2017, from https://www.forbes.com/sites/csr/2012/03/29/corporatesustainability-is-itself-unsustainable/2

Figs. (2017a). “Our Story.” Retrieved November 06, 2017, from https://www.wearfigs.com/pages/our-story

Figs. (2017b). “Threads for Threads.”Retrieved November 06, 2017, from https://www.wearfigs.com/pages/threads-for-threads

Flandez, R. (2011, March 20). How giving helped one business grow. Retrieved from https://www.philanthropy.com/article/ How-Giving-Helped-One-Business/226301

Freytas-Tamura, K. (2017, October 12). For dignity and development, East Africa curbs used clothes imports. New York Times. Retrieved November 6, 2017.

Herrera, A. (2013, March 19). Questioning the TOMS shoes model for social enterprise. New York Times.

Horoszowski, M. (2016, February 07). 64\% of CEOs are increasing investment in corporate social responsibility in 2016 - Here's why.

Jazner, C., \& Weinstein, L. (2015, November 17). The buy-onegive-one model might make you feel good, but it doesn't make the world better. Retrieved November 06, 2017, from https:// www.fastcompany.com/3053596/the-buy-one-give-one-modelmight-make-you-feel-good-but-it-doesnt-make-the-world-better

Joyner, A. (2017, June 18). Beyond buy-one-give-one retail. Retrieved November 05, 2017, from https://www.newyorker. com/business/currency/beyond-buy-one-give-one-retail

Kuota (2017). Our Cause. Retrieved November 06, 2017, from https://kutoa.com/pages/our-cause

Marquis, C., \& Park, A. (2014). Inside the buy-one give-one model [PDF]. Stanford: Stanford Social Innovation Review.

McPhee, W. (2014). A new sustainability model: engaging the entire firm. Journal of Business Strategy, 35(2), 4-12. doi:10.1108/jbs11-2013-0106

Moon, J. (2014). Corporate Social Responsibility. New York: Oxford University Press.

O’Connor, C. (2014, August 20). Bain deal makes TOMS shoes founder Blake Mycoskie a $\$ 300$ million man. Retrieved November 05, 2017, from https://www.forbes.com/sites/ clareoconnor/2014/08/20/bain-deal-makes-toms-shoesfounder-blake-mycoskie-a-300-million-man/\#2d49271a5668

One World Play Project. (2017). “Our giving.” Retrieved November 06, 2017, from https://www.oneworldplayproject.com/givesoccer-balls/

Out of Print Clothing. (2017). "Mission \& Impact.” Retrieved November 06, 2017, from https://www.outofprintclothing.com/ pages/mission

Pettinger, T. (2017). Infant Industry Argument. Retrieved April 10, 2018, from https://www.economicshelp.org/blog/glossary/ infant-industry-argument/
Ponte, S., \& Richey, L. A. (2014). Buying into development? Brand Aid forms of cause-related marketing. Third World Quarterly, 35(1), 65-87. doi:10.1080/01436597.2014.868985

Ponte, S., Richey, L. A., \& Baab, M. (2009). Bonos Product (RED) Initiative: corporate social responsibility that solves the problems of 'distant others'. Third World Quarterly, 30(2), 301-317. doi:10.1080/01436590802681074

Project 7. (2017). “Project 7’s Mission.” Retrieved November 06, 2017, from https://project7.com/pages/mission

Reed, R. (2017, March 22). One-for-None: Aid dependency and the "TOMS Model”. Retrieved November 06, 2017, from http:// harvardpolitics.com/world/one-for-none/

Rogers, F. (2017, Fall). View/Review: The pros \& cons of corporate social responsibility. Retrieved November 5, 2017, from https:// bbr.baylor.edu/corporate-social-responsibility/

Roma. (2017). "FAQ about Roma Boots.” Retrieved November 06, 2017, from https://romaboots.com/pages/faq

Schawbel, D. (2016, December 23). Neil Blumenthal: What he's learned from the success of Warby Parker. Retrieved November 05, 2017, from https://www.forbes.com/sites/ danschawbel/2016/12/23/neil-blumenthal-what-hes-learnedfrom-the-success-of-warby-parker/\#10ef39657143

Singer, J. (2016, February 23). Give a little, get a lot. Or not. Retrieved November 06, 2017, from http://www.therobinreport. com/give-a-little-get-a-lot-or-not/

Smile Squared. (2017). "Shared Smiles." Retrieved November 06, 2017, from https://smilesquared.com/sharing-smiles/

State Bags. (2017). “Give Back Pack.” Retrieved November 06, 2017, from https://www.statebags.com/pages/2017-give-backpack

Soapbox Soaps. (2017). “Soapbox.” Retrieved November 06, 2017, from https://www.soapboxsoaps.com/pages/mission

Spaulding, A., Fernandez, S., \& Sawayda, J. (2011). TOMS: One for One Movement [PDF]. Albuquerque: University of New Mexico.

The Economist. (2016, November 05). "Free two shoes." Retrieved November 06, 2017, from https://www.economist.com/news/ finance-and-economics/21709563-new-studies-should-coolwarm-glow-surrounding-shoe-donations-free-two-shoes?fsrc=sc n\%2Ffb\%2Fte\%2Fpe\%2Fed\%2Ffreetwoshoes

The Economist Intelligence Unit (2008). Executives say corporate citizenship can boost profits over time, according to new intelligence unit report [Press release].

This bar saves. (2017). “Our Cause.” Retrieved November 06, 2017, from https://www.thisbarsaveslives.com/pages/our-cause

Timmerman, K. (2011, April 06). The problem with TOMS shoes \& its critics. Retrieved from http://whereamiwearing. com/2011/04/toms-shoes/

TOMS. (2017a) "What we give." Retrieved October 02, 2017 from http://www.Toms.com/what-we-give-shoes

TOMS. (2017b). “Where we give.” Retrieved October 03, 2017 


\section{APPLIED SCIENCES}

from http://www.toms.com/where-we-give

TOMS. (2017c). “Giving Water.” Retrieved October 03, 2017 from http://www.toms.com/where-we-give

TOMS. (2017d). "Shoe giving partners.” Retrieved November 05, 2017 from http://www.Toms.com/shoe-partners

TOMS. (2017e). “Blake Mycoskie.” Retrieved December 10, 2017 from http://www.toms.com/blakes-bio

TOMS Giving Report [PDF]. (2013). TOMS Shoes.

Torres, A. (2013, Winter). TOMS Shoes: Philanthropic capitalism [PDF]. San Diego: University of California San Diego.

Twice as Warm. (2017). "How We Give.” Retrieved November 06, 2017, from https://twiceaswarm.com/about-us/

Utley, T. (2017, February 08). Meet Bombas, the social impact company that gave 2 million pairs of socks to the homeless. Retrieved November 06, 2017, from https://www.forbes. com/sites/toriutley/2017/02/06/meet-bombas-the-socialimpact-company-that-gave-2-million-pairs-of-socks-to-thehomeless/\#5d813298288b

Vogel, D. (2008, October 16). CSR doesn't pay [Web blog]. Retrieved http://www.forbes.com/2008/10/16/csr-doesntpay-lead-corprespons08-cx_dv_1016vogel.html

W, C. (2014, October 27). Putting the boot in development. Retrieved November 05, 2017, from https://www.economist. com/blogs/freeexchange/2014/10/economics-toms-shoes

Warby Parker. (2017). "Buy a pair, give a pair.” Retrieved November 05, 2017, from https://www.warbyparker.com/ buy-a-pair-give-a-pair

Watkins, T. (2012, January 20). How Oblierté, the anti-TOMS, makes shoes and jobs in Africa. Retrieved from https://www. good.is/articles/how-oliberte-the-anti-toms-makes-shoesand-jobs-in-africa

WeWood. (2017). “A tree story.” Retrieved November 06, 2017, from https://us.we-wood.com/a-tree-story

Wharton. (2015, February 16). "The one-for-one business model: Avoiding unintended consequences.” Knowledge@ Wharton. Retrieved from http://knowledge.wharton.upenn. edu/article/one-one-business-model-social-impact-avoidingunintended-consequences/

Wydick, B., Katz, E., \& Janet, B. (2014). Do in-kind transfers damage local markets? The case of TOMS shoe donations in El Salvador. Journal of Development Effectiveness, 6(3), 249267. doi:10.1080/19439342.2014.919012

Youde, J. (2009). Ethical consumerism or reified neoliberalism? Product (RED) and private funding for public goods. New Political Science,31(2), 201-220. doi:10.1080/07393140902872369 